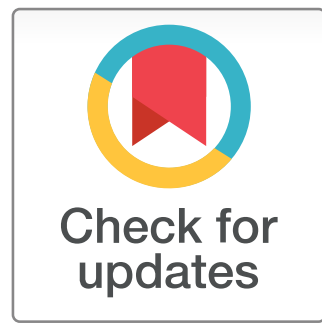

OPEN ACCESS

Citation: Roziqin, A., Retnandari, N. D., Fajrina, A. N., Sihidi, I. T., \& Kamil, M. (2021). The Local Government and Creative Industry: Experience from Batik Tulis Lasem Industries. Jurnal Bina Praja, 13(3), Industries. Jurnal Bina Praj 419-429. https://doi.org/10.21787/ jbp.13.2021.419-429

Received: 27 March 2021

Accepted: 16 November 2021

Published: 30 December 2021

(c) The Author(s)

\section{(c) (1) $\$(2)$}

This work is licensed under a Creative Commons Attribution-NonCommerciatShareAlike 4.0 International License.

\section{ARTICLE}

\section{The Local Government and Creative Industry}

\section{Experience from Batik Tulis Lasem Industries}

\author{
Ali Roziqin (D) ${ }^{1 匹}$, Nunuk Dwi Retnandari (D) ${ }^{2}$, Amaliana N. Fajrina (D) ${ }^{3}$, Iradhad T. \\ Sihidi (iD ${ }^{4}$, Muhammad Kamil (DD ${ }^{5}$ \\ 1,3, 4, ${ }^{5}$ Department of Government Studies, Faculty of Social \& Political Sciences, Universitas \\ Muhammadiyah Malang \\ ${ }^{2}$ Master of Public Administration, Faculty of Social \& Political Sciences, Universitas Gadjah Mada \\ valiroziqin@umm.ac.id
}

\begin{abstract}
Recently, Batik Tulis Lasem had several problems with a product, starting from input until the market process. Also, there is the problem of capital and technological capabilities from Batik Tulis Lasem industry, poverty, and social inequality of the craftsman. This article aims to examine the role of local government in improving creative industries, especially Batik Tulis Lasem. Further, this article was conducted by qualitative descriptive approach, particularly using the case study. In addition, the researchers collected data from semi-structured interviews with official local government and Batik TulisLasem entrepreneurs in the period covered 2018-2019. The results showed that local government has an important role in improving creative industries, firstly as a regulator, secondly as a facilitator, and thirdly to ensure the existence of Batik Tulis Lasem through empowerment. The problems in Batik Tulis Lasem are the regeneration of entrepreneurs, including batik craftsman, the lack of empowerment by local government, and the lack of information technology knowledge among the majority of Batik entrepreneurs. As an implication, the government should increase empowerment for the Batik Tulis Lasem industry through the regeneration program of batik craftsman and increase capacity for digital marketing.
\end{abstract}

Keywords: local government; creative industries; local economy; entrepreneurs; empowerment; Batik Tulis Lasem 


\section{Introduction}

In the last decade, the concept of a creative economy has grown in popularity in many countries, and its influence has extended around the world (Fahmi et al., 2017; Lee, 2016). Especially in developing countries, creative industry has a major role in improving the economy of the community, both nationally and regionally (Shafi et al., 2019; Zhou et al., 2020). The UK Department of Culture, Media and Sport established many sectors as part of the creative industries in 1998, which was the start of the importance of creative industries (Shafi et al., 2019). It means that creative industries play an important role in developing countries, especially their positive contribution to income and employment payments. In addition, creative industries can also be part of the community empowerment process.

Focused on Indonesia, the government has developed 16 sub-sectors in the creative industry, including games production and application, architecture, interior design, visual communication design, product design, fashion, film, photography, crafts, culinary, music, publishing, performing arts, fine arts, television, and radio. In 2017, the creative economy contributed US\$71.8 million to the country's GDP (Gross Domestic Product), increasing slightly in 2018 to US $\$ 78.9$ million. Furthermore, there are around $14.28 \%$ or 16.91 million people who work in the creative industry sector (Badan Ekonomi Kreatif, 2018). One of the creative industry instruments that contribute to this number is batik.

Batik is cultural and art product. Batik also has a high economic value. Batik is very famous in Indonesia and on an international level has been recognized by UNESCO as Indonesia's cultural heritage (Ratminto, 2015). As is known, Indonesian Batik products are mostly from Yogyakarta, Surakarta, and Pekalongan. However, recently many regions in Indonesia have developed batik as a creative industry. One of these is Lasem, Rembang Regency namely Batik Tulis (Made with Write/Art) Lasem. Historically, Batik Tulis Lasem is a type of coastal batik. As a region close to the beach, Lasem has a culture closely related to the values coastal communities. In addition, Lasem has an acculturation value with China. Firstly, Batik Tulis Lasem is used as a finger or scarf by local communities. However, because of the development and dynamic in society, Batik Tulis Lasem now has high economic value and economic resources for most Lasem communities.

In the new millennium, Batik Tulis Lasem has been transformed into a creative industry in Rembang Regency. However, as well as creative industry products in general, many problems have arisen. For instance about a product, namely how to make a marketable product from the stages of input, process, to output (Tahwin et al., 2015). There is also the problem of poverty and social inequality of the craftsman (Listyorini, 2012), and the limitations of batik entrepreneurs in utilizing capital and technological capabilities (Desmaryani, 2017; Haryono \& Fathoni, 2017). In addition, the future of Batik Tulis Lasem is increasingly threatened by the arrival of imported batik, at a far cheaper price. Further, Batik Tulis Lasem has to face an uncertain market situation as a result of the development of information technology in the community or often known as the disruption era (Kasali, 2017).

Based on the problems above, local governments have an important role to help overcome the problems experienced by the creative industries especially Batik Tulis Lasem. This argument is supported by Drab-Kurowska (2018) who describes that creative industries in the context of the economy are explored not only by scholars but also by government or political decision-makers, including those in economic development strategies. As a result, the government, both local and regional were asked to play their role in the development of the creative industries (Desmaryani, 2017). In the Indonesian Government context, it has many roles in relation to the welfare of the communities.

Since the end of the New Order period, Indonesia entered a new phase of the reform era in which the government implemented a decentralized system. The local government can be regarded as the manifestation of administrative decentralization 
(Datta, 2013). This has impacted the regions competing to develop their potential to gain economic benefits, including the development of the local economy. According to Law Number 23 of 2014 about the Local Government, it states that the implementation of local government has the aim to accelerate the realization of community welfare, both through improved services, empowerment, and community participation, as well as an increase in regional competitiveness by considering the principles of equality, justice, democracy and the uniqueness of an area in a system of the Unitary State of Indonesia Republic. Certainly, this condition also has an impact on the growing economy in the local regions.

This article aims to identify how the role of local government supports creative industries, specifically Batik Tulis Lasem. In recent years many scholars have discussed about Batik Tulis Lasem, exploring cultural values and more economic aspects, such as products, marketing, business strategies, etc. (Haryono \& Fathoni, 2017). However, there are still very few studies on the role of local government to intervene in creative industries for the welfare of society. Based on this fact, the government can become a facilitator to support the development of creative industries (Chen et al., 2013). In addition, another article by Asim et al. (2019) describes that government regulations can accelerate the development of creative industries. According to Luken and Van Rompaey (2008), high production prices, existing environmental laws, and projected potential environmental legislation are the three key drivers of sustainable development, including for creative industries in developing countries.

In many countries, the creative industries have become the mainstay and new orientation in economic development. Despite that, the policy on creative industries might only benefit the middle class (Fahmi et al., 2017), thereby contributing on social gap (Peck, 2005). to diffuse creative to as to have a positive impact on all of the people, several countries have issued policies. For instance, in Taiwan through the Triple Helix framework. The results involve R\&D institutions (Research and Development) such as ITRI (Industrial Technology Research Institute) and HSIP (Hsinchu Science-based Industrial Park), which can enhance the development of SMEs as a part of creative industries (Chen et al., 2013). In addition, China uses a triple helix framework to improve nanotechnology industries in the globalization process (Cheng et al., 2019). In South Korea, triple helix institutional actors, including university-industry-government (U-I-G), will certainly boost the country's innovation capabilities (Lee \& Kim, 2016). The triple helix concept has three key actors, namely universities/Scholars, Industries, and Government (Etzkowitz, 2012). But this article is only limited to discuss the role of government in the Triple Helix framework in improving creative industries because in many studies still limited discussion from a government perspective.

The concept of the triple helix both in practice and theory, has been widely used to develop industries in various countries. Several countries in Asia, such as Singapore, Taiwan, South Korea, and China, are very concerned about the development of SMEs and their creative industries (Bennett et al., 2015; Chen et al., 2013; Fahmi et al., 2017). Creative industries in an area can develop rapidly through innovation and promotion by utilizing financial resources and other potential resources they have (Low \& MacMillan, 1988). Using the triple helix approach, is expected to bring up innovation, skills, creativity, and ideas in the development of the creative industries.

The triple helix has several networks linking university, government, and industry partners. The three sectors can interact, assume or share the positions of each other in part, and exert their impact on each other in different ways (Cheng et al., 2019; Choi et al., 2015; Etzkowitz, 2012). All three collaborate with each other dynamically and continuously. Since it was first popularized by and Etzkowitz and Leydesdorff (1997), the triple helix concept has developed according to the actors involved, even unlimited (Leydesdorff, 2012). Further, the triple helix allows creating policy collaboration and innovation (Diercks et al., 2019) that effective in the development of creative industries. 
Figure 1. A Conceptual Framework of Triple Helix

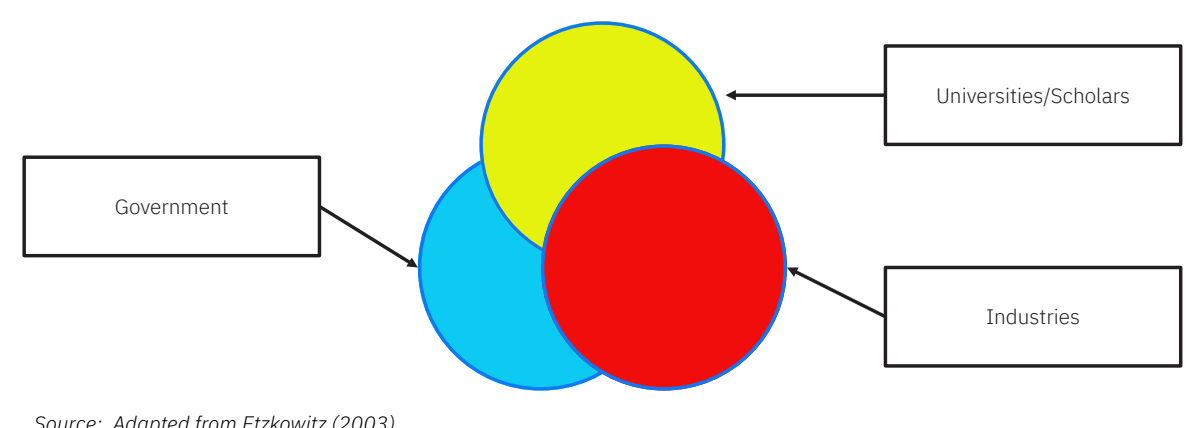

Source: Adapted from Etzkowitz (2003)

Etzkowitz explained that the government in the triple helix was described as a field that could move the community to improve skills, ideas, and creativity, while universities have a role in development of innovation and technology (Desmaryani, 2017). The business or industry in the triple helix is used to introduce innovative practices and procedures for entrepreneurship development, which businesses are believed to make capitalization that can provide social-economic benefits for the community (Etzkowitz, 2003, 2012).

Empirically, the triple helix concept further emphasizes the role of universities and industries, as described by Etzkowitz in his article entitled "Triple helix clusters: boundary permeability at university-industry-government interfaces as a regional innovation strategy" (Etzkowitz, 2012). Although the role of government remains, the portion is smaller. Specifically, the role of local government plays an important role, especially in developing countries, where the government dominates all economic functions. Another study says that in the triple helix concept in Singapore and China, the government is only a "principal player" in the development of creative industries (Naughton, 2007; Wong, 2001). Therefore, researchers focused on the role of government because it can set out of supporting policy or strategy to improve creative industries (Chen et al., 2013).

\section{Methods}

The article tries to analyze how the local government improves creative industries, specifically Batik Tulis Lasem. This article employed a qualitative descriptive approach because this research aims to describe the phenomenon and its characteristics (Nassaji, 2015), using the case of Batik Tulis Lasem industries. Qualitative analysis is sufficient for this research through a single case study, as it exploits opportunities to investigate a significant phenomenon (Eisenhardt \& Graebner, 2007). The researchers collected data through semi-structured interviews, non-participant observation (Weerakoon \& Fernando, 1990), literature study, and documents analysis related to the research focus. In addition, the researchers also use the case study to investigate social phenomena in a specific local context (Yin, 2014), more specifically in the Batik place. Meanwhile, the locus of research is Lasem District. Some informants are bureaucrats at the Department of Industry, Trade, and Cooperatives (Rembang Regency), Head of Regional National Crafts Council (Rembang Regency), Head of Batik cluster, Entrepreneurs of Batik Tulis Lasem, and batik craftsman. Further, the researchers used inductive exploration data analysis by identifying and interpreting both primary and secondary data relevant to the focus of the study. This research process took 6 months, from September of 2018 until February 2019.

The researchers used data triangulation techniques by Huberman and Miles (2012) for data verification and validation, which consists of data reduction, presentation, and conclusion. Conclusions are described to answer research questions. Therefore, the information presented is accurate and reliable. Further, following the concept of the triple helix. This article emphasizes the aspects of governance that involve government, industry, and academia. Although the discussion 
presented by the researcher focus more on the government aspect as the main actor of this network. This research was conducted as an answer to the gap of discussion of research on Batik Tulis Lasem from a governance and policy perspective.

\section{Results and Discussion}

\subsection{The Role of Government and Creative Industries}

Organizational creativity plays a key role in achieve goals (Indriartiningtias et al., 2019), including the organizational role, such as government. The role of government through institutional in the creative industries is a driving force to improve the local economy (Desmaryani, 2017). On the same point, as a concept that continues to develop following empirical studies, this triple helix concept produces three forms of paradigm. Firstly, a static regime, where the government functions as a director to encourage universities and industries. Secondly, a laissez-faire regime is a driving force with the other two parties as an ancillary support structure. Thirdly, the balance model, involves the role of the three parties based on knowledge (Hakim et al., 2018). Further, the focus of this research is on the static regime paradigm; Therefore, the approach used focuses on aspects of government.

Several studies explain that the creative industry is a government strategy to increase economic growth (Jayne, 2005; Lin \& Chiu, 2019). Government strategy plays an important role in maintain creative industries as a local identity (Smith \& Warfield, 2007). In regard to experience from other nations, Farzin (2017) explained that the role of government is to prepare policy infrastructure; support with insights from policy makers and industries to understand different expectations. The policies and support take the form of loans, training, education, manufacturing of supporting facilities, tax breaks, special regional regulations, and cooperation between public and private organizations. Meanwhile, innovation and training will support entrepreneurial activities in Birjand, Iran (Farzin, 2017). Support from the government for the creative industries not only increases social economy, but also humanistic value and social equality (Drab-Kurowska, 2018), including in an Indonesian government context.

Since the Indonesian government uses the concept of decentralization, local governments have the right to manage their regions independently. This means the central government gives the widest possible autonomy to regional governments. According to Law Number 23 of 2014, it is argued that the implementation of regional government has the aim of accelerating the realization of people's welfare, as well as improving regional competitiveness by taking into account the principles of equity, justice, democracy, and the uniqueness of an area in the Unitary State of The Republic of Indonesia. Furthermore, according to Law Number 24 the Year 2019 Concerning Creative Economy, it is mandated that the government and/or regional governments must be responsible for creating and developing creative economic ecosystems, so that they will be able to contribute to the national economy and increase global competitiveness in order to achieve the goal of sustainable development. In this case, the creative industries are part of the creative economy.

The increasing competition, many countries rely on local characteristics and creativity (Bennett et al., 2015; Jiang et al., 2019). Through human knowledge and creativity, wealth development is rapidly outpacing the production of wealth from natural resources. According to the United Nations Institute for Training and Research (UNITAR), the creative industries are the most innovative field in the global economy, with a strong transformative force for socio-economic growth. An industry is said to be a creative industry if creativity is the main component (Indriartiningtias et al., 2019).

The concept of creative industries has its debate among scholars. Do the creative industries include the arts and culture sector or the culture industry itself? (Daniel, 2016), which is justified by Fahmi et al. (2017) in that, especially in creative industries in developing countries. Because each country has a different understanding, for example, North America, Australia, and Europe, which is used as tools to regenerate the economy and revitalize impoverished communities, especially in de-industrialized 
Table 1. The Number of Industries That Related with Batik in Rembang Regency countries (Gibson \& Kong, 2005; Pratt, 2008). Moreover, this tends to be economic innovation activities in most of the Asia Pacific countries (Bae \& Yoo, 2015; Chen et al., 2013; Farzin, 2017).

In Indonesia's context, creative industries are more interpreted as traditional cultural industries, such as crafts (Fahmi et al., 2017), because so many areas that develop creative industries start from inherent cultural values. Since the creative industry was first introduced in Bandung, West Java, many other regions have gradually formulated similar policies. Furthermore, under the Jokowi government, Indonesian creative industries received intense attention with the issuance of the Presidential Regulation of Indonesian Public Number 72 of 2015 about the Creative Economic Agency (Bekraf) in charge of 16 creative economic sub-sectors, including the Batik Tulis Lasem Industries. The government has even issued Law number 24 of 2019 on the creative economy.

\subsection{Conditions of Batik Tulis Lasem Industry}

Batik is a work of art and culture from Indonesian society that has been passed down from generation to generation. In general, batik is more often found among Javanese communities both inland and coastal areas (Maulany \& Masruroh, 2017). Batik Tulis Lasem is a type of coastal batik with foreign cultural influences, especially in China. Especially in the Districts of Pancur and Lasem, many home-based Batik Tulis Lasem industries have become local people's livelihoods.

Firstly, Batik Tulis Lasem was a work of art that had no economic value, but gradually the community's interest in batik continued to increase. Thereby encourages entrepreneurs who are of Chinese descent to produce in large quantities. In its journey, Batik Tulis Lasem, it was in its heyday in the 70s, but in the late 90s and early 2000 the Lasem written batik industry suffered a setback. The result was that Batik Tulis Lasem entrepreneurs waited for a while. However, better conditions began to be felt by entrepreneurs when batik was recognized as Indonesia's original cultural heritage.

In 2018, the number of Lasem Batik entrepreneurs was around 120 industries, with a total workforce of 4,444 spread across several districts in the Rembang Regency. The total number is able to produce 379,757 pieces of fabric. In recent years, many entrepreneurs have begun to utilize the digital era to expand their market reach (marketing). The majority of them use social media platforms such as WA, Twitter, Facebook, and Instagram, while the rest use websites and e-commerce media or the marketplace. Although it has succeeded in increasing the use of online platforms by batik entrepreneurs, the impact has not been significant, as can be seen from Table 1. According to data from the Department of Industry, Trade, and Cooperatives in Rembang Regency, an increase in two types of industry was contributed by the batik industries.

\begin{tabular}{llllllll}
\multicolumn{1}{c}{ Type of Industries } & 2012 & 2013 & 2014 & 2015 & 2016 & 2017 & 2018 \\
Fabric Clothing & 2213 & 2231 & 2256 & 2297 & 2317 & 2335 & 2370 \\
\hline Craft industries and general & 2995 & 2011 & 3250 & 3295 & 3337 & 3352 & 3382 \\
\hline
\end{tabular}

Source: Central Agency on Statistics, Rembang Regency

During the developments and changes in the community, Batik Tulis Lasem industries need to follow suit. This means that, if today, many people use the internet, the Batik Tulis Lasem industries also need to use the internet and e-commerce as a business model. Especially the small-scale industries that are vulnerable to change.

\subsection{Local Government as a Regulator}

The government's role as a regulator aims to regulate, supervise, and protect creative industry products from internal and external threats (Desmaryani, 2016; Roziqin \& 
Fajrina, 2021). It is a reminder that the creative industry is one of the economic pillars of the local community. To increase the role of creative industries for society's economy, first, the Central Government of Indonesia (Under President Susilo Bambang Yudhoyono) issued Presidential Instruction number 6 of 2009 concerning the development of the creative economy. This instruction is imperative to all government institutions, including local governments (Sidauruk, 2013). Starting from that, local governments have developed creative industries based on their creativity and cultural values. Moreover, the creative industries can help drive the regional economy.

Based on the direction of economic development policies in the medium term 2015-2019, the Rembang Regency government strives that the economy of Rembang Regency not only grow in terms of results, but also in terms of quality. It was to promote inclusive and sustainable economic growth. Increasing economic growth is expected to be an incentive for inclusive buildings to generate employment and reduce poverty and inequality. One of the tools is utilizing the Batik Tulis Lasem industries. In this case, all levels of the Rembang Regency Government have agreed to protect and guarantee Batik Tulis Lasem at the heart of which there is a batik stamp and a global fashion industry. This is evidenced by the existence of Regent's Regulation No. 29 of 2017 concerning the preservation of Batik Tulis Lasem, which is stated in Clause 3 about the purpose of preservation of Batik Tulis Lasem:

1. Preserving Batik Tulis Lasem;

2. Preserving the practice of traditional batik making in Batik Tulis Lasem as a cultural property of the local community;

3. Improving the standard of living from craftsman and community.

On the other side, Regent (Abdul Hafidz) has also issued a Bupati Decree containing the obligation for bureaucrats to wear the Batik Tulis Lasem uniform. Furthermore, since 2018 students from elementary-high school level have been required to wear the Batik Tulis Lasem every Friday. The political will in the form of regulations and decisions can be said to be one of the efforts made to maintain Batik Tulis Lasem as a work of art and culture that has high selling points. In addition, this regulation also provides legal certainty that Batik Tulis Lasem is batik traditionally written by batik artisans.

As a high-value local product, Batik Tulis Lasem is also entitled to intellectual protection. Therefore, local governments encourage craftsman to have Intellectual Property Right certificates to protect their products from plagiarism by others. However, some entrepreneurs actually only register their trademarks because the registration process becomes easy. In addition, the claim process is also easier if there is plagiarism.

The local government also continues to protect the existence of Batik Tulis Lasem through cross-organizational collaboration, both private institutions, NGOs, and universities, and the local government makes several programs to revitalize Batik Tulis Lasem. One of the flagship programs is the batik love movement which is held every year at the commemoration of Kartini's day. This program aims to introduce the younger generation to the potential of Batik Tulis Lasem. These educational and promotive programs have introduced Batik Tulis Lasem nationally and even internationally. This condition has an impact on product demand that continues to increase so that the existence of the Batik Tulis Lasem industry is not eroded by changing times.

\subsection{Local Government and Universities as a Facilitator}

Synergy between the government and universities has an important role in providing facilitation in knowledge and technology to batik entrepreneurs (Desmaryani, 2017; Etzkowitz, 2012). In improving Batik Tulis Lasem Industries, Rembang Regency Government and the universities also act as a facilitator, both in the form of assistance, training, and workshop activities. The government says that they will continue to strive 
to develop Lasem Batik consistently, as stated by staff at the Department of Industry, Trade, and Cooperative:

"We are from the government and always trying to facilitate of development of Batik TulisLasem. Starting from business management training, bookkeeping, coloring, product promotion, and recently online marketing and the like. While the training that has been done, for example, is creating Blogspot" (Interview with Muhammad Siddiq, Head of Industrial Section, 24 September 2018).

Meanwhile, universities facilitate good management processes. As done by STIE YPPI Rembang in the industrial internship program. Several universities in the Central Java region, such as Semarang State University and Diponegoro University are also actively conducting coaching and facilitation. Such as providing business capital assistance, facilitation of batik business equipment, and IPR registration. It was recorded that in 2018 there were 21 batik motifs that had Intellectual Property Rights. Through active involvement by the university, it is hoped that it will be able to transfer knowledge to Batik entrepreneurs.

In addition, since 2009, the government has built a batik cooperative showroom. This showroom serves as a place to showcase the work of the Batik Tulis Lasem craftsman. In terms of promotion, the government is also actively providing exhibition stands (expo) both at national and international levels in rotation to the batik industries, and having creative economic products which are then widely known can increase regional competitiveness and investment at the national or international level (Haryotedjo, 2012; Saksono, 2012).

In 2020, Regency Government, through the Regent H. Abdul Hafidz, wants to encourage the progress of Batik Tulis Lasem by creating Lasem Written Batik industry clusters. The Regency Government has prepared a budget of Rp50 billion (Kabupaten Rembang, 2020). Of course, it is recognized as an integral part of a broader marketing strategy (Zheng, 2011). The existence of this cluster is expected to be a unique motif from Batik Tulis Lasem that will be better known to the wider community. In addition, the historical value possessed by Lasem Batik also has the potential to become a tourist power for the community.

\subsection{Government: Empowerment Institutions}

The majority of Batik Tulis Lasem industry is a home industry. As such, many craftsmen are from rural communities with low educational backgrounds. Therefore, to empower Lasem batik entrepreneurs, the local government of Rembang Regency through the Department of Industry, Trade, and Cooperative has established Lasem written batik clusters in 2005, with the aims of facilitating the coordination between Batik Tulis Lasem entrepreneurs. In addition, the cluster also functions as a place to provide training and even internship opportunities at the Pekalongan batik industry center. It aims to bring up new entrepreneurs in the Batik sector.

"Through the Department of Industry, Trade, and Cooperative, Rembang Regency Government (Dinindagkop), several pieces of training were given to batik entrepreneurs, including training in coloring, bookkeeping, monitoring to improve production and business management. So, what is needed and desired by IKM (small and medium industries) we always try facilitating" (Translated by Interview with Joko Santoso, Head of Data Processing, Department of Industry, Trade and Cooperatives, 20 September 2018).

The existence of these programs aim is to improve productivity and the environment that prioritizes the small and medium-scale batik industry. These batik entrepreneurs receive training, development, and coaching to improve their skills and competencies in developing the industry. This effort is trying to be a tangible form so that the Batik Tulis Lasem industry grows into a profitable industry.

However, training, and empowerment are not yet optimal because there are still many obstacles, especially related to online marketing. This fact is also followed by 
the role of the university which has not been maximized in equipping entrepreneurs with e-marketing skills. Many entrepreneurs miss understanding the mechanism of selling online and using e-commerce platforms. Even though this digital situation can be an opportunity and a challenge for the Batik Tulis Lasem industry. Why is that? Because if digitalization is utilized at maximum, it will increase broader marketing reach and act as a promotional medium. Conversely, if it does not utilize well, the Lasem Batik industry will not compete with similar industries.

Another problem in the Batik Tulis Lasem Industry is the low regeneration of batik makers. The majority of batik craftsmen are women and old mothers. As a result, batik production also has limitations because it depends on the capacity of craftsmen. The government has not been able to create a conducive environment, which can attract the young generation to enter the Batik Tulis Lasem industries.

\section{Conclusion}

This study has examined how the local government improves creative industries. Adopted the triple helix concept, the role of local government was supported by universities and Batik Tulis Lasem industries itself. The Local government plays an important role in improving the creative industry as a driving force. In the case of Batik Tulis Lasem, the local government has played a role in at least three things:

1. Regency Government as a regulator

2. Regency Government as a facilitator supported by universities

3. Regency Government as empowerment institutions.

The advancement of creative industries will have a socio-economic impact on society. Therefore, the local government needs to intervene in managing the Batik Tulis Lasem.

This article found that the majority of a craftsman of Batik Tulis Lasem were elderly mothers. There is also the problem of the lack of empowerment carried out by the local government, and an understanding of the limited information technology from the majority of Batik Tulis Lasem entrepreneurs. Therefore, the local government needs to focus more on empowerment to the Lasem Batik industries. This needs to maintain the sustainability of Batik Tulis Lasem industries in the future. In addition. this article has limitations by only focusing on the role of local government. Although starting from the triple helix concept, the researchers consider that the government has always been a key player in enhancing the creative industries. Another side, universities do not have a maximum role in transferring knowledge and technology. It is evidenced by the fact that many batik entrepreneurs have not mastered emarketing technology. It shows that the discussion of the role and the university and industry itself can be studied in more depth in the next article.

\section{Acknowledgment}

We would like to express our gratitude to Universitas Muhammadiyah Malang, which has supported this publication. Also, the first author says thanks to Dr. Nunuk Dwi Retnandari as a supervisor and give some advice on this manuscript.

\section{References}

Asim, S., Li, C., Makhdoom, H. U. R., \& Zafar, Z. (2019). Entrepreneurial Technology Opportunism and Its Impact on Business Sustainability with the Moderation of Government Regulations. Entrepreneurial Business and Economics Review, 7(3), 161-185. https://doi.org/10.15678/EBER.2019.070309

Badan Ekonomi Kreatif. (2018). Infografis Ringkasan Data Statistik Ekonomi Kreatif.

Bae, S. H., \& Yoo, K. (2015). Economic modeling of innovation in the creative industries and its implications. Technological Forecasting and Social Change, 96, 101-110. https://doi.0rg/10.1016/ j.techfore.2015.02.010

Bennett, J., Woods, R., Bower, N., Bruce, S., \& O'Connor, G. (2015). Creative councils for creative communities. Broadway. https://apo.org.au/node/57649

Chen, C., Lin, Y.-L., \& Chu, P.-Y. (2013). Facilitators of national innovation policy in a SME-dominated country: A case study of Taiwan. Innovation, 15(4), 405-415. https://doi.org/10.5172/ impp.2013.15.4.405 
Cheng, Y., Liu, Y., Fan, W., Yan, Z., \& Ye, X. (2019). Triple helix on globalization: A case study of the China International Nanotech Innovation Cluster. Information Development, 35(2), 272-289. https://doi.org/ 10.1177/0266666917743050

Choi, S., Yang, J. S., \& Park, H. W. (2015). Quantifying the Triple Helix relationship in scientific research: statistical analyses on the dividing pattern between developed and developing countries. Quality \& Quantity, 49(4), 1381-1396. https://doi.org/10.1007/s11135-014-0052-5

Daniel, R. (2016). Policy development and engagement: perspectives and insights from key stakeholders involved in the creative industries in north Queensland, Australia. International Journal of Cultural Policy, 22(2), 256-272. https://doi.org/10.1080/10286632.2014.985667

Datta, P. K. (2013). Making Local Self-Government in Rural India Work: Old Tradition and New Challenges. Indian Journal of Public Administration, 59(1), 93-110. https://doi.org/10.1177/0019556120130108

Desmaryani, S. (2016). The Implementation of SWOT Analysis of People Economic Empowerment Business Loan (KUPEM) in Jambi Province. Jurnal Bina Praja, 8(2), 305-315. https://doi.org/10.21787/ jbp.08.2016.305-315

Desmaryani, S. (2017). The Role of Regional Government in Growing Small and Medium Enterprises' Performance towards Creative Industry in Jambi Province. Jurnal Bina Praja, 9(1), 159-169. https:// doi.org/10.21787/jbp.09.2017.159-169

Diercks, G., Larsen, H., \& Steward, F. (2019). Transformative innovation policy: Addressing variety in an emerging policy paradigm. Research Policy, 48(4), 880-894. https://doi.org/10.1016/ j.respol.2018.10.028

Drab-Kurowska, A. (2018). State intervention in the context of creative industries. Management, 22(1), 7484. https://doi.org/10.2478/manment-2018-0006

Eisenhardt, K. M., \& Graebner, M. E. (2007). Theory Building From Cases: Opportunities And Challenges. Academy of Management Journal, 50(1), 25-32. https://doi.org/10.5465/amj.2007.24160888

Etzkowitz, H. (2003). Innovation in Innovation: The Triple Helix of University-Industry-Government Relations. Social Science Information, 42(3), 293-337. https://doi.org/10.1177/05390184030423002

Etzkowitz, H. (2012). Triple Helix Clusters: Boundary Permeability at University-Industry-Government Interfaces as a Regional Innovation Strategy. Environment and Planning C: Government and Policy, 30(5), 766-779. https://doi.org/10.1068/c1182

Fahmi, F. Z., McCann, P., \& Koster, S. (2017). Creative economy policy in developing countries: The case of Indonesia. Urban Studies, 54(6), 1367-1384. https://doi.org/10.1177/0042098015620529

Farzin, F. (2017). Localising the impact of techno-entrepreneurship in Eastern Iran: Birjand's Science and Technology Park as a local innovation community. Local Economy: The Journal of the Local Economy Policy Unit, 32(7), 692-710. https://doi.org/10.1177/0269094217734327

Gibson, C., \& Kong, L. (2005). Cultural economy: a critical review. Progress in Human Geography, 29(5), 541-561. https://doi.org/10.1191/0309132505ph567oa

Hakim, L., Solihat, A., Setiawati, S. D., \& Roisah, R. (2018). Implementasi Triple Helix pada Inkubasi Bisnis Outwall. Jurnal Abdimas BSI: Jurnal Pengabdian Kepada Masyarakat, 1(3), 379-389. https://doi.org/ 10.31294/jabdimas.v1i3.4037

Haryono, A. T., \& Fathoni, A. (2017). Potensi Batik Lasem Sebagai Upaya Pengembangan Ekonomi Kreatif untuk Meningkatkan Keunggulan Kompetitif Berkelanjutan di Kecamatan Lasem Kabupaten Rembang. Jurnal Ekonomi Dan Bisnis Kontemporer, 3(2). http://jurnal.unpand.ac.id/index.php/EBK/article/view/ 875

Haryotedjo, B. (2012). Analisis Iklim Investasi Daerah (Studi Kasus: Kota Semarang). Jurnal Bina Praja, 4(1), 01-10. https://doi.org/10.21787/JBP.04.2012.01-10

Huberman, A., \& Miles, M. (2012). Understanding and Validity in Qualitative Research. In The Qualitative Researcher's Companion (pp. 36-64). SAGE Publications, Inc. https://doi.org/ 10.4135/9781412986274.n2

Indriartiningtias, R., Subagyo, \& Hartono, B. (2019). Creativity of small firms in creative industry: Initial evidence from Indonesia. International Journal of Engineering Business Management, 11, 184797901984913. https://doi.org/10.1177/1847979019849135

Jayne, M. (2005). Creative Industries: The Regional Dimension? Environment and Planning C: Government and Policy, 23(4), 537-556. https://doi.org/10.1068/c0453

Jiang, Y., Qian, Q., Zhang, X., \& Chen, Y. (2019). The Formation of Government-Oriented Creative Community and Its Driving Mechanisms: A Case Study of the $39^{\circ}$ Space Art Creative Community in Foshan, China. Sustainability, 11(3), 625. https://doi.org/10.3390/su11030625

Kabupaten Rembang. (2020, January 16). Dorong Kemajuan Batik Tulis Lasem dengan Pembuatan Kluster. https://rembangkab.go.id/berita/dorong-kemajuan-batik-tulis-lasem-dengan-pembuatan-kluster/

Kasali, R. (2017). Era Disruption. Gramedia Pustaka Utama.

Lee, H.-K. (2016). Politics of the 'creative industries' discourse and its variants. International Journal of Cultural Policy, 22(3), 438-455. https://doi.org/10.1080/10286632.2014.991783

Lee, Y. H., \& Kim, Y. (2016). Analyzing interaction in R\&D networks using the Triple Helix method: Evidence from industrial R\&D programs in Korean government. Technological Forecasting and Social Change, 110, 93-105. https://doi.org/10.1016/j.techfore.2015.10.017

Leydesdorff, L. (2012). The Triple Helix, Quadruple Helix, ..., and an N-Tuple of Helices: Explanatory Models for Analyzing the Knowledge-Based Economy? Journal of the Knowledge Economy, 3(1), 25-35. https:// doi.org/10.1007/s13132-011-0049-4

Lin, W.-I., \& Chiu, S.-Y. (2019). The mobilisation of creative city building as a new mode of governmentality in Dihua Street neighbourhood, Taipei City. Geoforum, 106(May 2018), 320-329. https://doi.org/ 10.1016/j.geoforum.2018.05.002 
Listyorini, H. (2012). Komponen dan Dampak Social Entrepreneurship Upaya Revitalisasi Budaya dan Industri Kabupaten Rembang. Dinamika Kepariwisataan, XI(2), 48-57. https://www.unisbank.ac.id/ ojs/index.php/pdk1/article/view/1720

Low, M. B., \& MacMillan, I. C. (1988). Entrepreneurship: Past Research and Future Challenges. Journal of Management, 14(2), 139-161. https://doi.org/10.1177/014920638801400202

Luken, R., \& Van Rompaey, F. (2008). Drivers for and barriers to environmentally sound technology adoption by manufacturing plants in nine developing countries. Journal of Cleaner Production, 16(1), S67-S77. https://doi.org/10.1016/j.jclepro.2007.10.006

Maulany, N. N., \& Masruroh, N. N. (2017). Kebangkitan Industri Batik Lasem di Awal Abad XXI. Patra Widya: Seri Penerbitan Penelitian Sejarah Dan Budaya, 18(1), 1-12. https://doi.org/10.52829/pw.43

Nassaji, H. (2015). Qualitative and descriptive research: Data type versus data analysis. Language Teaching Research, 19(2), 129-132. https://doi.org/10.1177/1362168815572747

Naughton, B. J. (2007). The Chinese Economy: Transitions and Growth. MIT Press.

Peck, J. (2005). Struggling with the Creative Class. International Journal of Urban and Regional Research, 29(4), 740-770. https://doi.org/10.1111/j.1468-2427.2005.00620.x

Pratt, A. C. (2008). Creative cities: the cultural industries and the creative class. Geografiska Annaler: Series B, Human Geography, 90(2), 107-117. https://doi.org/10.1111/j.1468-0467.2008.00281.x

Ratminto. (2015). Skenario Optimis Pengembangan Batik Jogja. In Manajemen Publik Kontemporer. Gava Media.

Roziqin, A., \& Fajrina, A. N. (2021). Will Creative Industries Survive in Industrial Revolution 4.0? An Experience from Batik Tulis Lasem, Indonesia. Proceedings of the 1st International Conference on Law and Human Rights 2020 (ICLHR 2020), 549(Iclhr 2020), 252-258. https://doi.org/10.2991/ assehr.k.210506.035

Saksono, H. (2012). Ekonomi Kreatif: Talenta Baru Pemicu Daya Saing Daerah. Jurnal Bina Praja, 04(02), 93-104. https://doi.org/10.21787/JBP.04.2012.93-104

Shafi, M., Sarker, M. N. I., \& Junrong, L. (2019). Social Network of Small Creative Firms and Its Effects on Innovation in Developing Countries. SAGE Open, 9(4), 215824401989824. https://doi.org/ $10.1177 / 2158244019898248$

Sidauruk, R. (2013). Peningkatan Peran Pemerintah Daerah dalam Rangka Pengembangan Ekonomi Kreatif di Provinsi Jawa Barat. Jurnal Bina Praja, 05(03), 141-158. https://doi.org/10.21787/ JBP.05.2013.141-158

Smith, R., \& Warfield, K. (2007). The Creative City: A Matter of Values. In Creative Cities, Cultural Clusters and Local Economic Development. Edward Elgar Publishing. https://doi.org/ 10.4337/9781847209948.00021

Tahwin, M., Dewi, D. A. L., \& Mahmudi, A. A. (2015). Supply Chain Usaha Kecil Menengah (Studi Kasus Industri Batik Tulis Lasem Kabupaten Rembang). The 2nd University Research Coloquium 2015, 4, 71-79. https://jurnal.unimus.ac.id/index.php/psn12012010/article/view/1490

Weerakoon, P. K., \& Fernando, D. N. (1990). Observer evaluation as a tool for field level evaluation of performance. Medical Teacher, 12(3-4), 311-314. https://doi.org/10.3109/01421599009006636

Wong, P. K. (2001). Leveraging multinational corporations, fostering technopreneurship: the changing role of S\&T policy in Singapore. International Journal of Technology Management, 22(5/6), 539. https:// doi.org/10.1504/IJTM.2001.002977

Yin, R. K. (2014). Case Study Research: Design and Methods (5th ed.). SAGE.

Zheng, J. (2011). 'Creative Industry Clusters' and the 'Entrepreneurial City' of Shanghai. Urban Studies, 48(16), 3561-3582. https://doi.org/10.1177/0042098011399593

Zhou, J., Li, J., Jiao, H., Qiu, H., \& Liu, Z. (2020). The more funding the better? The moderating role of knowledge stock on the effects of different government-funded research projects on firm innovation in Chinese cultural and creative industries. Technovation, 92-93(November), 102059. https://doi.org/ 10.1016/j.technovation.2018.11.002 